\title{
External Debt, Domestic Debt and Economic Growth: The Case of Nigeria
}

\author{
Dal Didia*, Phillip Ayokunle \\ College of Business Administration, Jackson State University, the United States
}

Received January 17, 2020; Revised February 18, 2020; Accepted February 24, 2020

Copyright $\bigcirc 2020$ by authors, all rights reserved. Authors agree that this article remains permanently open access under the terms of the Creative Commons Attribution License 4.0 International License

\begin{abstract}
The unprecedented accumulation of public debt is a source of anxiety for many Nigerians. Rather than serve as a catalyst for economic development, the debt is now a drag on economic development as Nigeria is struggling to service the interest on these loans, let alone the principal. Furthermore, the pressure to service these loans leads to a myriad of myopic policies that are totally detrimental to the interests of sustainable development. This study therefore examines the impact of public and publicly guaranteed debt on the economic growth of Nigeria. The study disaggregates total public and publicly guaranteed debt into external debt and domestic debt, and examines whether the two kinds of debt have differential impact on economic growth in Nigeria. Utilizing data from the Central Bank of Nigeria, and the World Bank, our empirical analysis using the Vector Error Correction Model (VECM) and covering 1980 - 2016, revealed that domestic debt has a statistically significant positive relationship with economic growth in the long run while external debt exhibiting a negative relationship with economic growth was not statistically significant. The lesson here is that domestic debt appears to be more beneficial in terms of economic growth in Nigeria than external debt as interest paid on domestic loans remains in the country and could be put into further productive economic use. As a policy recommendation from this study, the Federal Government of Nigeria may want to start paying more attention to the mix of domestic debt and external debt in Nigeria’s loan portfolio.
\end{abstract}

JEL Codes: F3, O4

Keywords External Debt, Domestic Debt, Economic Growth, Nigeria

\section{Introduction}

Many countries engage in borrowing to finance their budget deficits and critical infrastructure. In the case of developed countries such as Organization for Economic Cooperation and Development (OECD) countries with strong institutions and adequate checks and balances, the borrowed funds are by and large invested in the projects for which they were acquired. In the quest for rapid economic development, Sub-Saharan African countries (SSA) are borrowing heavily from external and internal sources. The major problem with the debt accumulation of SSA is that there is not much to show by way of economic development for the huge amounts of debt accumulated. According to the World Bank (2014), by 2012, the total external debt of SSA stood at $\$ 333.1$ billion and by 2018, the total debt had increased to $\$ 364.5$ billion. About 60 percent of these loans that must be serviced with foreign exchange earnings are public or publicly guaranteed. The pressure to service these loans leads to a myriad of myopic policies that are totally detrimental to the interests of sustainable development as Von Moltke (1990) and Kahn and McDonald (1995) observed. As it is today, rather than be a catalyst for economic development, the debt is now a drag on economic development as these countries are unable to service the interest on these loans, let alone the principal.

One of the SSA countries that is heavily indebted is Nigeria, a country with both the largest population (200 million) and gross domestic product ( $\$ 398$ billion) in the region as of 2018. By the year 2000, Nigeria's total public and publicly guaranteed debt (external and domestic) stood at $\$ 13$ billion, and by 2016, the amount had grown to $\$ 47$ billion. A breakdown of these loans in 2016 reveals that $\$ 11$ billion (24\%) are external loans while \$36 billion (76\%) are domestic. External debt refers to debt sourced from the capital markets and other sources outside Nigeria while domestic debt refers to debt sourced from the capital market and other sources within Nigeria. Servicing these debts for which there is not much on the ground in terms of economic development has now become a substantial burden on the country. For Nigeria, total debt as a 
percentage of Gross Domestic Product (GDP) rose from $5 \%$ in 1980 to $12 \%$ in 2016. Since external debts must be serviced in hard currency such as the dollar or pound, a better measure of the ability to service these loans would be export earnings. So for Nigeria, export earnings as a percentage of GDP fell from 36\% in 2000 to 9\% in 2016. Clearly, these debt levels are unsustainable as export earnings are quite volatile and declining in a monoculture economy where crude oil exports account for about $80 \%$ of foreign exchange earnings and about $60 \%$ of total government revenue.

Recently, a body of literature has emerged (as we discuss in section II) attempting to discern the differential impacts of external debt and domestic debt on economic development. This line of inquiry is warranted because external debt may impact economic growth differently from domestic debt for a number of reasons. First, external loans have conditions and strings attached to them that do not apply to domestic loans. For instance, external debt must be serviced in hard currency such as the dollar or euro; they may have conditions on how they are utilized which may include that the borrower must purchase needed items from the creditor regardless of the availability of cheaper alternatives elsewhere. More importantly, due to the weakness of institutions and widespread corruption in Nigeria, a significant percentage of external loans may not reach the shores of Nigeria

Available literature, as we discuss in section II, seems to suggest that the research on the differential impact of external debt and domestic debt on economic growth in Nigeria is still in its infancy with mixed results. This study therefore adds to the existing body of knowledge or literature by examining whether or not external debt and domestic debt have a differential impact on economic growth in Nigeria. The study is clearly warranted because, first, Nigeria is heavily indebted; it is the largest country in SSA both in population and GDP, and the country is looked upon as the future of SSA if she can get her house in order. Therefore, economic progress or the lack thereof in Nigeria has implications for the rest of SSA in general and West Africa in particular.

The remainder of the paper is organized as follows: section II takes on a review of the literature while section III discusses data and methodology. Section IV discusses the empirical analysis while summary and conclusion follow under section V.

\section{Literature Review}

The quest for economic development in many cases require governments to borrow. However, money borrowed is meant to cover government's budget deficit with an expected economic growth and development in return. For instance, Egbetunde (2012) in his analysis of causal link between public debt and economic growth in
Nigeria found that there is a long-run positive relationship between public debt and economic growth. He concluded that in the long-run there would be economic growth if the government makes judicious use of the loans for the development of the economy. Rapu et al (2014) empirically concurred that public debt is significantly and positively related to GDP growth. In their quest to examine fiscal deficit, debt dynamics and growth in Nigeria from 1970 to 2011, their result indicates that a 10 percent increase in public debt leads to a 3 percent increase in the country's GDP.

The possibility of relative positive outcomes between public debt and growth lies in the government's efforts to maintain low budget deficit, low debt-to-GDP ratio and that the debt should be used mainly for capital projects. Otherwise, the government will face a situation where public debt suppresses the growth of the economy especially when there is a rise in debt over time and the debt is not well managed. In support of this, while examining the break effects between Greek government's debt and its economic growth several years after the financial crisis, Pegkas (2018) discovered that as government debt rose beyond the year 2000, its effect on economic growth diminished very rapidly and the growth impacts turned negative. Gomez-Puig and Sosvilla-Rivero (2016) also tested as to whether the impact of public debt differs in short and long-run using annual data from both central and peripheral countries of the European Monetary Union (EMU) from 1960 to 2012. Their findings reveal that public debt has always negatively impacted long-run performance of EMU countries. In like manner, Siddique et al. (2015) found that in both short and long-run, a reduction in debt stock would significantly increase the growth performance in highly indebted poor nations. Other studies that provided negative evidence between accumulation of public debt and economic growth in developing countries include Zouhaier and Fatma (2014); Lawanson (2014) and Were (2001).

Although, several studies might have found a negative or positive relationship between public debt and economic growth, there has not been a strong conclusion on the subject as countries both in developed and developing or emerging economies are distinctly peculiar in their own ways of managing debt and the application of it. Hence, Panizza's and Presbitero's (2013) findings state that there is no monotonic relationship between debt and growth. Furthermore, Calderon and Fuentes (2013) investigated whether the burden of government debt affects economic growth prospects. Their findings include an adverse effect of debt on growth, but with high quality domestic policies in place, the effect can be easily mitigated in both developed and developing nations. Therefore, these reasons provide neutrality for debt-growth relationship. Hence, the impact of debt on economic growth is a still an open question.

Foreign debt is meant to cover foreign exchange gap and 
investment-saving gap. Theoretically, foreign exchange gap is the payment of deficit that confronts a nation when its external reserve has been reduced to a minimum compared to its import requirements, while investment-saving gap represents foreign capital needed to support domestic savings for financial real investment level. While the verdict on the impact of public debt on economic growth remains inconclusive, studies have begun to investigate whether or not external debt and domestic debt have a differential impact on economic growth. This is in an attempt to further understand how debt impacts economic growth.

Sulaiman and Azeez (2012) empirically examined the effect of external debt on the economic growth in Nigeria and found that external debt is beneficial to the economy, thus, a unit increase in external debt increases the GDP by 0.094117. From their study, they came to a conclusion that the optimal utilization of external debt by the government would avoid debt overhang and crowding-out investments. Similarly, Ezema, Nwekwo and Agbaji (2018) revealed that external debt positively and significantly impacted economic growth in Nigeria. Ezema's et al. (2018) findings suggest that Nigeria's external debt plays a significant role in improving economic growth but accumulation of external debt services has resulted in a steady increase in debt burden both in 1990s and early part of 2016 .

In their examination of the reasons behind the ineffectiveness of external debt on economic growth in Nigeria, Akhanolu, Babjide and Akinjare (2018) recommended that mismanagement of borrowed funds should be tackled at all cost. This type of corruption does not only add to the level of debt and its services for the country but also cripples the level of investments that would have been otherwise achieved. As Maxwell (1993) noted, a larger part of these external debts is used to service internal debt. Furthermore, government guaranteed foreign debt produces destabilizing effects by stimulating capital flight (Maxwell, 1993). Similarly, Ogunmuyiwa (2002) argued that external debt only helps to exploit the potentials of a country; it does not enhance it. He further argued that the debt burden of a country and the outcomes of debt service impose a setback on the economy in terms of insufficient foreign exchange to finance importation of raw materials and capital goods needed for economic growth. Moreover, in line with the conceptual belief, Nigerian government's inability to service its external debt increased the external debt burden on the entire country, which in turn limited the growth of the economy. Ayadi and Ayadi (2008) buttressed on this by adding that Nigeria has been experiencing difficulties in servicing her debt which further exacerbates the pressure on its debt stock due to recapitalization of arrears. The authors concluded that external debt has not been utilized prudently in Nigeria, and that the country could manage its debt stock more efficiently through consistent debt management strategies, prudential borrowing, persistent servicing of debt, and possible liquidation of all outstanding external debt.

While the studies cited above indicate that external debt may be inimical to economic growth, Akhter and Hassan (2012) used both public debt and growth models to investigate the claim that Bangladesh is excessively borrowing to sustain its economy. Their findings do not support the assertion that external debt has a negative impact on economic growth in the country.

Comparatively, some studies agree that domestic debt is superior to external debt in terms of overall impact on economic growth and development, and that the accumulation of domestic debt adds significantly to the development process of a country. These studies reveal that an increase in domestic debt leads to increases in government expenditure with its ripple effects on total demand, production and employment. Akhanolu et al. (2018) stated that domestic debt is effective in economic growth because it significantly impacts the distribution of goods and services, capital accumulation, income growth, unemployment, stability and much more. Nba, Yuni and Oburota (2013) added that domestic debt has a significant and direct relationship with GDP but debt servicing is inversely related to GDP. The implication of their findings is that domestic debt should be invested in the productive sector especially the real sector of the economy for further productivity gains within the economy. The interest paid on such loans would represent a crowd-in effect that encourages growth.

Contrarily, Rapu (2003) experimented with the sustainability of domestic debt stock level vis-à-vis GDP in Nigeria using the budget constraints model. He found that under the current fiscal deficit, government domestic debt is not sustainable. He concluded that it would only result in an economically catastrophic situation for the country due to low level or absence of government primary surplus, unsustainable economic growth and inefficient management of the debt. In evaluating Nigeria's domestic debt stock, Anochie, Ude and Osuji (2015) found that domestic debt leads to 43 percent reduction in economic growth in Nigeria. Reasons behind these negative effects were identified in their study as high budget deficit, high inflation, low-output level, narrow revenue base and higher government expenditure. The authors therefore recommended that the government should increase its revenue base through tax reforms, pay off its debt and use the money borrowed for the intended reasons. In terms of credit constraints faced by local investments, domestic debt is found to crowd-out private sector credit by an elasticity of 0.3 percent of GDP, preventing capital accumulation and private investment growth (Mbate, 2014).

In an examination of cause-effect relationship between public debt and economic growth in India, Manik (2016) concluded that there is no feedback relationship between domestic debt and economic growth. Considering debt-GDP threshold which is plausible by many studies, Reinhart and Rogoff (2010) having analyzed data from 
forty-four countries over a period of two hundred years concluded that there is a weak relationship between domestic debt and real GDP growth especially for debt/GDP threshold below 90 percent of GDP.

Lastly, over the years whether domestic or external debt, Nigeria has not fully enjoyed the returns that were meant to accrue from loans due to mismanagement. In lieu of this, public loans are categorized into reproductive and deadweight. Ajayi and Oke (2012) defined reproductive loan as when a loan is used by the state or nation to procure some sort of assets. For example, money borrowed for acquiring factories, electricity, refineries and so on. Debt for the purpose of financing war and expenses on recurrent expenditure are dead weight debt. The authors stated that a debtor country will have to import from the creditor country goods and services to the value of loan borrowed without having to export anything in exchange. In order to repay this loan, the debt-financed investment needs to be productive with a higher rate of return than the cost of servicing it. In support of this argument, Ajayi and Oke found that there is a positive relationship between national income and debt service, external reserve and interest rate payment in Nigeria from 1970 to 2007. This implies that when debt of any kind is used for reproductive investments and well managed, it is positively related to economic growth and development through a boost in national income.

From prior research, there is evidence of weak conclusions on the actual impact of public debt on economic growth in both developed and developing nations. In spite of these findings, countries seeking rapid economic growth continue to access capital markets worldwide, anticipating that debt could be more beneficial to the society than what had been reported in some cross-country studies. Hence, more research is needed on a country-by-country basis. Against this background, this study intends to further analyze the effect of public and publicly guaranteed debt on economic growth in Nigeria using a new data set from 1980 to 2016. Furthermore, total debt will be disaggregated into external debt and domestic debt and the impact on GDP will be examined. We hope that this study will shed more light on the unresolved issue of the impact of public debt on economic growth.

\section{Data and Methodology}

\subsection{Data Description and Sources}

The annual time series data used in this study covers a period of 1980 to 2016. The data were sourced from the World Bank and the Central Bank of Nigeria Statistical Bulletin. GDP, a proxy for economic growth, is the dependent variable. The independent variables include domestic debt (dd), external debt (ed), and other determinants of GDP - foreign direct investments (fdi), net official development assistance or official aid (aid), government expenditure (govt), foreign exchange earnings (exe), and total debt service (tds) - that are usually included in studies of this nature.

\subsection{Model Specification}

The empirical analysis employs the Classical Ordinary Least Square Method (OLS), Augmented Dickey Fuller (ADF) Unit-Root Test, Johansen Co-Integration Test and Vector Error Correction Model (VECM) using version 15 of the STATA software. Specifically, we adopted VECM to estimate both short and long-term relationships between domestic debt, external debt and economic growth. Following Dritsaki (2013), and employing the Neo-Classical Production Function, the econometric model is specified thus:

$$
\text { gdp } \left.=\text { f(dd, ed, } v^{\prime}\right)
$$

where

gdp = gross domestic product $($ proxy for economic growth)

$\mathrm{dd}=$ total domestic debt as percentage of gdp

ed $=$ total external debt as a percentage of gdp

$\mathrm{v}^{\prime}=$ other determinants of GDP such as foreign direct investment, foreign aid, government expenditures, export earnings and debt service.

Equation (1) is represented in the vector error correction model as thus:

$$
\begin{aligned}
& \Delta \operatorname{Lngdp}_{t}=a_{10}+\lambda\left(\Delta \operatorname{Lndd}_{t-1}-\beta \Delta L \operatorname{Lngdp}_{t-1}\right)+\sum a_{11, i} \Delta \operatorname{Lngdp}_{t-1}+ \\
& i=1 \\
& \rho \quad \rho \\
& \sum_{i=0} a_{12, i} \Delta \operatorname{Lndd}_{t-i}+\sum_{i=0} a_{13, i} \Delta \text { Lned }_{t-i}+V_{t}^{\prime}+\mathcal{E}_{1 t}
\end{aligned}
$$




$$
\begin{aligned}
& \Delta \operatorname{Lndd}_{t}=a_{20}+\eta\left(\operatorname{Lndd}_{t-1}-\beta \Delta \operatorname{Lngdp}_{t-1}\right)+\sum_{i=1}^{\rho} a_{21, i} \Delta \operatorname{Lndd}_{t-1}+ \\
& \text { p } \\
& \sum_{i=0} b_{22, i} \Delta \operatorname{Lngdp_{t-i}}+\sum_{i=0} \alpha_{23, i} \Delta \operatorname{Lned}_{t-i}+V_{t}{ }_{t}+\mathcal{E}_{2 t} \\
& \text { Lned }_{t}=a_{30}+\Omega\left(\text { Lned }_{t-1}-\beta \Delta \operatorname{Lngdp}_{t-1}\right)+\sum_{i=1}^{\rho} a_{31, i} \Delta \text { Lned }_{t-1} \\
& \rho \\
& +\sum_{i=0} b_{32, i} \Delta \operatorname{Lngdp}_{t-i}+\sum_{i=0} \alpha_{33, i} \Delta \operatorname{Lndd}_{t-i}+V_{t}^{\prime}+\mathcal{E}_{3 t}
\end{aligned}
$$

Where,

$\mathrm{a}, \mathrm{b}$ and $\alpha=$ parameters

$\lambda, \eta, \Omega=$ the speed of adjustment parameters.

$\mathrm{V}_{\mathrm{t}}{ }_{\mathrm{t}}=$ control variables (other determinants of GDP)

$\varepsilon_{\mathrm{t}}=$ a zero mean white noise error term.

$\rho=$ number of lags

A priori, we expect $\mathrm{dDLndd} / \mathrm{dDLngdp}<0$; and $\mathrm{dDLned} / \mathrm{dDLngdp}<0$. Our expectation is that due to high level of mismanagement of public funds in Nigeria, and because money borrowed is not properly used for the original intentions, debts of any form only reduce the performance of the economy as a whole.

\section{Empirical Results}

\subsection{Estimation Technique}

The variables were log transformed to keep them at the same level. Frist, we ran regression analysis of the already log transformed independent and dependent variables and discovered that the estimation could be spurious due to high R-square (95\%) and low Durbin Watson Test (1.1845). Regression results are presented below in table 1.

We tested for stationarity of the time series by employing Augmented Dickey-Fuller (ADF) Test, and the data became stationary after the first lag with drift. Since the times series were stationary after the first lag with the stationarity process of $\Delta L n g d p_{t}=L n g d p_{t}-\operatorname{Lngdp}_{t-1}$, we tested to examine if there is a long run relationship among the variables by employing Johansen Co-integration Test. There is more than one co-integration equation among the variables which affirms the use of VECM adopted in this study. The fact that the data were not stationary until after the first difference and the variables are co-integrated, necessitates the use of VECM. The results of Augmented Dickey-Fuller (ADF) Test, Johansen Co-Integration Test, and both short and long-run VECM results are shown in tables 2, 3, 4 and 5 respectively.
Table 1. Regression Analysis Dependent Variable = Lngdp

\begin{tabular}{|c|c|c|}
\hline Independent Variables & Coefficients & P > t \\
\hline Lndd & -0.2551325 & 0.283 \\
\hline Lned & 0.2348511 & 0.244 \\
\hline Lnfdi & -0.3094622 & $0.053^{*}$ \\
\hline Lnaid & 0.3363659 & $0.000^{* * *}$ \\
\hline Lngovt & 0.8337742 & $0.000^{* * *}$ \\
\hline Lnexe & 0.0532944 & 0.741 \\
\hline Lntds & -0.1803456 & $0.071^{*}$ \\
\hline Constant & 4.647556 & $0.002^{* *}$ \\
\hline No. of Obs. & 36 & \\
\hline F(7, 28) & 81.64 & \\
\hline R-square & 0.9533 & \\
\hline Adjusted R- Square & 0.9416 & \\
\hline Durbin Watson & 1.184527 & \\
\hline Lignifance at $* * * \%$ & $* 5 \%$. & \\
\hline
\end{tabular}

Level of significance at $* * * 1 \%, * * 5 \%$ and $* 10 \%$ level and $\mathrm{P}>\mathrm{ItI}$ represents the probability.

gdp = gross domestic product

$\mathrm{dd}=$ total domestic debt as percentage of gdp

ed $=$ total external debt as a percentage of gdp

$\mathrm{fdi}=$ foreign direct investment

aid $=$ net official development assistance or official aid

govt $=$ government expenditures

exe $=$ exports earnings as a percentage of gdp

tds $=$ total debt service as a percentage of foreign exchange earnings

Table 2 reveals ADF Test results in which after first difference the variables became stationary. The co-integration test result in table 3 shows that there are three co-integration equations at $1 \%$ and $5 \%$ critical values (using Trace statistic and the critical values). That is, there is a long-term relationship among the variables. This, however, requires that we reject the null hypothesis that there is no co-integration at rank 0,1 , and 2 at both $1 \%$ and $5 \%$ critical values, and rank 3 at 5\%, while we fail to reject 
the null hypothesis at rank 4, 5, 6 and 7 at both $1 \%$ and 5\% critical values, and at rank 3 , we also fail to reject the null hypothesis at $1 \%$ critical value. The implication of this is that gross domestic product, domestic debt as a percentage of GDP and external debt as a percentage of GDP including other determinants of GDP variables used are co-integrated. Typically, it exposes the trend of these variables over the years, especially domestic debt and external debt. Hence, we proceeded to correct these errors by employing VECM model.

Table 2. Augmented Dickey-Fuller Test for Unit Root

Number of obs. $=35$

\begin{tabular}{|c|c|c|c|c|c|c|}
\hline $\begin{array}{c}\text { No of } \\
\text { lags }\end{array}$ & Variable & $\begin{array}{c}\text { Test } \\
\text { Statistic }\end{array}$ & $\begin{array}{c}1 \% \text { Critical } \\
\text { Value }\end{array}$ & $\begin{array}{c}5 \% \text { Critical } \\
\text { Value }\end{array}$ & $\begin{array}{c}10 \% \text { Critical } \\
\text { Value }\end{array}$ & $\begin{array}{c}\text { Mackinnon Appr. P-value for } \\
\text { Z(t) }\end{array}$ \\
\hline 1 & DLngdp & -3.208 & -2.453 & -1.696 & -1.309 & $0.0016^{* *}$ \\
\hline 1 & DLndd & -2.814 & -2.453 & -1.696 & -1.309 & $0.0114^{* *}$ \\
\hline 1 & DLned & -3.086 & -2.453 & -1.696 & -1.309 & $0.0021^{* *}$ \\
\hline 1 & DLnfdi & -4.371 & -2.457 & -1.697 & -1.310 & $0.0001^{* * *}$ \\
\hline 1 & DLnaid & -5.503 & -2.453 & -1.696 & -1.309 & $0.0000^{* * *}$ \\
\hline 1 & DLngovt & -3.035 & -2.457 & -1.697 & -1.310 & $0.0025^{* *}$ \\
\hline 1 & DLnexe & -4.455 & -2.453 & -1.696 & -1.309 & $0.0001^{* * *}$ \\
\hline 1 & DLntds & -4.568 & -2.453 & -1.696 & -1.309 & $0.0000^{* * *}$ \\
\hline
\end{tabular}

Level of significance at $* * * 1 \%, * * 5 \%$ and $* 10 \%$ level and P-value for ZItI represents the probability.

Table 3. Johansen Co-integration Test Results

\begin{tabular}{|c|c|c|c|c|}
\hline Maximum Rank & Perm & Trace Stat & 5\% Critical Value & 1\% Critical Value \\
\hline 0 & 72 & 210.1971 & 156.00 & 168.36 \\
\hline 1 & 87 & 157.4678 & 94.15 & 103.18 \\
\hline 2 & 100 & 110.8075 & 68.52 & 76.07 \\
\hline 3 & 111 & $75.8185 * 1$ & 47.21 & 54.46 \\
\hline 4 & 120 & $45.4844 * 5$ & 29.68 & 35.65 \\
\hline 5 & 127 & 25.9054 & 15.41 & 20.04 \\
\hline 7 & 132 & 10.2953 & 3.76 & 6.65 \\
\hline
\end{tabular}

*indicates the level of significance at $1 \%$ and $5 \%$ 
Table 4. VECM Results (Short-Run Relationship among the variables)

\begin{tabular}{|c|c|c|c|c|}
\hline No. of Lags & D_Lngdp Equation & Coef. & $\mathbf{P}>\mathbf{l z l}$ & Standard Error \\
\hline 1 & L1_ce1 & -0.0623558 & 0.247 & 0.0538075 \\
\hline 1 & D_Lndd & 0.045 & 0.852 & 0.2417748 \\
\hline 1 & D_Lned & 0.1436687 & 0.419 & 0.1779002 \\
\hline 1 & D_Lnfdi & -0.025404 & 0.752 & 0.0803091 \\
\hline 1 & LD_Lnaid & 0.0061469 & 0.944 & 0.0870137 \\
\hline 1 & LD_Lngovt & -0.1025629 & 0.553 & 0.1730593 \\
\hline 1 & LD_Lnexe & -0.1411155 & 0.371 & 0.157766 \\
\hline \multirow[t]{7}{*}{1} & LD_Lntds & -0.0508626 & 0.563 & 0.0880145 \\
\hline & _cons & 0.0084741 & 0.881 & 0.056634 \\
\hline & No. of obs $=$ & 34 & & \\
\hline & R-square= & 0.5201 & & \\
\hline & $\mathrm{AIC}=$ & 1.049093 & & \\
\hline & HQIC= & 3.39149 & & \\
\hline & $\mathrm{SBIC}=$ & 7.917715 & & \\
\hline
\end{tabular}

Level of significance at $* * * 1 \%, * * 5 \%$ and $* 10 \%$ level and $\mathrm{P}>$ IzI represents the probability.

Table 5. VECM Results (Long-Run Relationship among the Variables)

Johansen-Normalization Restriction Imposed

\begin{tabular}{|c|c|c|c|c|}
\hline No. of Lags & D_Lngdp Equation & Coef. & P>lzl & Standard Error \\
\hline 1 & L1_ce1 & & & 1.270744 \\
\hline 1 & D_Lndd & -2.147087 & $0.091^{*}$ & 1.030921 \\
\hline 1 & D_Lned & 1.553352 & 1.51 & 0.6582724 \\
\hline 1 & D_Lnfdi & -1.396613 & $0.034^{* *}$ & 0.447225 \\
\hline 1 & LD_Lnaid & 0.3698222 & 0.408 & 1.043072 \\
\hline 1 & LD_Lngovt & -2.015103 & $0.053^{*}$ & 0.7582377 \\
\hline 1 & LD_Lnexe & -2.032206 & $0.007^{* *}$ & 0.424875 \\
\hline
\end{tabular}

Level of significance at $* * * 1 \%, * * 5 \%$ and $* 10 \%$ level and $\mathrm{P}>$ IzI represents the probability. 
The result in table 4 reveals the short-run relationship between economic growth, domestic debt, external debt and other determinants of GDP. From the table, there is no statistically significant relationship between economic growth, domestic debt and external debt but they are positively related. Similarly, other variables used in the analysis such as foreign direct investment, government expenditure, export earning as a percentage of GDP and total debt service as a percentage of foreign exchange earnings exhibit negative coefficients but no statistically significant relationship with GDP. Official development assistance shows positive coefficients but again, no statistically significant relationship with GDP.

Table 5 presents a long-run relationship among the variables. It is very important to note here that according to the rule of thumb in the Johansen-Normalization Restriction model (Johansen, 2002), the long-run adjustment process changes the signs of the coefficients in table 5 . Hence, the results are interpreted against the output result signs. That is, negative coefficients in table 5 are now interpreted as positive and vice versa to reflect the adjustment process in the long-run relationship between the variables.

From the long-run VECM model (table 5), domestic debt shows a statistically significant positive relationship with economic growth in the long-run. If domestic debt as a percentage of GDP increases by 1 percent, economic growth increases by approximately 2.15 percent, ceteris paribus. There is a negative although non-significant interaction between external debt as a percentage of GDP and economic growth in the long run. Other determinants of GDP such as foreign direct investment, federal government expenditure, export earnings as a percentage of GDP and total debt service as a percentage of foreign exchange earnings have a positive and statistically significant relationship with economic growth in the long-run. If these determinants of GDP go up by 1 percent, economic growth would increase by almost 1.397, 2.015, 2.03 and 2.71 respectively.

\subsection{Findings}

In the short-run, the coefficients of both domestic and external debts were positive in relation to the Nigerian economy but are ultimately not statistically significant. Hence, we focus on the long-run findings. In the long-run, the findings of this study provide support for the common assertions that domestic debt is more beneficial in terms of economic growth than external debt. These findings are in line with the findings of Akhanolu et al. (2018); Nba et al. (2013) and Ogunmuyiwa (2002). Some of the reasons why domestic debt is good for economic growth include the fact that the money remains in the economy even after paying the principal loan plus interest. When the repayment is made by the government to the lenders, the money could still be used within the economy for further production. Except official development assistance, other determinants of GDP have a statistically significant relationship with economic growth in the long-run. For instance, if foreign direct investment is encouraged to thrive through good policies, it does help the growth of the economy in the long-run; government expenditure on capital projects might take a while to bring forth its fruits but its long-run effect is huge and could trigger economic growth.

\section{Summary and Conclusions}

This study examined the impact of public and publicly guaranteed debt on economic growth in Nigeria from 1980 to 2016. This period was chosen because it presents a period with minimum gaps in the data. Unlike previous studies that dumped all debt together, this study disaggregated debt into external debt and domestic debt, and examined if there was a differential impact on economic growth. The results confirmed that domestic debt has a statistically significant positive impact on economic growth while external debt with a negative coefficient was not statistically significant.

The unambiguous lesson from this study is that the federal government of Nigeria needs to look inward when there is a need to borrow. When borrowed locally, any interest paid on such loans remains in the country and could be put back into further productive economic use. Although, there are instances when capital goods such as military equipment and other goods would be imported since they are not produced within the country and that involves borrowing from abroad, but government should minimize this type of borrowing in order to mitigate the negative effect of external debt on economic growth. Domestic borrowing will help provide jobs for the unemployed and taxes accrue to the government unlike borrowing money from abroad. In any event, this study recognizes that there may be instances where engaging external debt may be inevitable or more advantageous.

In Ricardo's theory of public debt, Roberts (1942) stated that Ricardo argued that taxes were the best agents of extraordinary government spending. He argued that taxes paid amounted to money saved for expenditure without diminishing national capital whereas money borrowed would by interest distort national capital. Government can also make safety net available for the poor through taxation and still have tangible savings to execute needed projects such as infrastructural development, and security of life and property.

This study has limitations that can be improved upon by future studies. First, we would recommend that future studies replicate this study or engage in a similar study in order to ascertain the robustness of our findings. Furthermore, future studies would improve on the findings of this study by increasing the number of observations beyond the 36 years covered in this study. A study covering more years will affirm the robustness or stability of the 
results and conclusions reached in this study. Since development studies adopt more or less ad-hoc models, future studies are encouraged to include other determinants of GDP not covered in this study. In spite of the limitations of this study, we hope that the study has made the relationship between debt and GDP a little more apparent.

\section{REFERENCES}

[1] Ajayi, L., \& Oke, M. (2012). Effect of External Debt on Economic Growth and Development of Nigeria. International Journal of Business and Social Science, Vol. 3, No. 12, pp. 297-304.

[2] Akhanolu, I., Babajide, A., \& Akinjare, V. (2018). The Effect of Public Debt on Economic Growth in Nigeria: An Empirical Investigation. International Business Management, Vol. 12, No. 6, pp. 436 - 441.

[3] Akhter, T., \& Hassan, H. M. (2012). Impact of Public Debt Burden on Economic Growth: Evidence from Bangladesh. Retrieved 09 12, 2019, from SSRN: https://papers.ssrn.co m/sol3/papers.cfm?abstract_id=2577214

[4] Akomolafe, K., Olanike, B., Oni, E., \& Achukwu, M. (2015). Public Debt and Private Investment in Nigeria. Retrieved 09 18, 2019, from Scientific and Academis Publishing: http://article.sapub.org/10.5923.j.economics.20150505.10. html

[5] Anochie, U. C., Ude, D. K., \& Osuji, O. (2015). Evaluating the Nigeria's Domestic Public Debt Stock: Implications to Economic Growth. Journal of Empirical Economics, Vol. 4, No. 6, pp. 298-312.

[6] Ayadi, F., \& Ayadi, O. F. (2008). The Impact of External Debt on Economic Growth: A Comparative Study of Nigeria and South Africa. Retrieved 09 12, 2019, from Journal of Sustainable Development in Africa:http://www. jsd-africa.com/

[7] Calderón, C., \& Fuentes, R. J. (2013). Government Debt and Economic Growth. Chile: Inter-American Development Bank - IDB WORKING PAPER SERIES No. IDB-WP-424.

[8] Central Bank of Nigeria (CBN) https://www.cbn.gov.ng/do cuments/Statbulletin.asp

[9] Dritsaki, C. (2013). Causal Nexus Between Economic Growth, Exports and Government Debt: The Case of Greece.

Retrieved from Science Direct: https://www.sciencedirect. com/science/article/pii/S2212567113000312

[10] Egbetunde, T. (2012). Public Debt and Economic Growth in Nigeria: Evidence from Granger Causality. American Journal of Economics, Vol. 2, No. 6, pp. 101 - 106.

[11] Ezema, C., Nwekwo, N., \& Agbaji, B. (2018). Impact of External Debt and its Services Burden to Economic Growth in Africa: Econometric Evidence from Nigeria 1990 - 2016. International Journal of Academic Research in Economics and Management Sciences, Vol. 7 No. 3, pp. 232-250. Retrieved from Journal International Journal of Academic
Research in Economics and Management Sciences: http://dx.doi.org/10.6007/IJAREMS/v7-i3/4643

[12] Gomez-Puig, M., \& Sosvilla-Rivero, S. (2016). Debt-Growth Linkage in EMU across Countries and Time Horizon. Retrieved 09 12, 2019, from Research Institute of Applied Economics - Working Paper 2016/10 1/37 pág.: http://www.ub.edu/irea/working_papers/2016/201610.pd

[13] Hadhek, Z., \& Mrad, F. (2014). "Debt and Economic Growth". Retrieved 09 12, 2019, from International Journal of Economics \& Financial Issues: https://econjournals.com /index.php/ijefi/issue/view/43

[14] Johansen, S. (2002, 10 21). The Interpretation of Cointegrating Coefficients in the Cointegrated Vector Autoregressive Model. Retrieved from Kobenhavns Universitet: https://soeg.ku.dk/?q=Johansen+Soren\&gcse= 003802773804381141234\%3A2j5u8uupemo

[15] Kahn, J. and McDonald, J. (1995). "Third World Debt and Tropical Deforestation", Ecological Economics 12, 107-123.

[16] Lawanson, A. O. (2014). Impact of External Debt Accumulation and Capital Flight on Economic Growth of West African Countries. Retrieved 09 12, 2019, from African Economic Research Consortium, Nairobi - AERC Research Paper 279: https://www.africaportal.org/publicati ons/impact-external-debt-accumulation-and-capital-flight-e conomic-growth-west-african-countries/

[17] Manik, N. (2016). "Causal Nexus between Public Debt and Economic Growth: The Case of India." Retrieved 09 12, 2019, from International Affairs and Global Strategy IISTE: https://www.iiste.org/Journals/index.php/IAGS/arti cle/view/31702

[18] Maxwell, J. F. (1993). Foreign Debt Accumulation: Financial and Fiscal Effects and Monetary Policy Reactions in Developing Countries. Journal of International Money \& Finance, Vol. 12, Issue 4, pp. 347 - 367.

[19] Mbate, M. (2014). "Domestic Debt, Private Sector Credit and Economic Growth in Sub - Saharan Africa". Retrieved from African Development review: https://onlinelibrary.wi ley.com/doi/pdf/10.1111/1467-8268.12040\#accessDenialL ayout

[20] Ogunmuyiwa, M. (2011). "Does External Debt Promote Economic Growth in Nigeria?" Current Research Journal of Economics Theory, Vol. 3, No.1, pp. 29-35.

[21] Panizza, U., \& Presbitero, A. F. (2013). "Public Debt and Economic Growth in Advanced Economies: A Survey". Swiss Journal of Economics and Statistics, Vol. 149, No. 2, pp. 175-204. Retrieved 09 12, 2019, from Springer Open: https://www.springeropen.com/search?query=public+debt +and+economic+growth+in+advanced+economies\&search Type=publisherSearch

[22] Pegkas, P. (2018). "The Effect of Government Debt and Other Determinants on Economic Growth The Greek Experience". Retrieved 09 12, 2019, from MDPI: Economies 2018, 6, 10; doi:10.3390/economies6010010

[23] Rapu, S. (2003). Assessment of Nigeria Domestic Debt Sustainability. Retrieved 09 12, 2019, from Google.com: http://library.cbn.gov.ng:8092/jspui/bitstream/123456789/ 325/1/Assessment\%20of\%20nigeria\%27s\%20domestic\%2 
Odebt\%20sustainability.pdf

[24] Rapu, S., Akpan, D., Ikenna-Ononugbu, A., \& Ajala, K. (2014). Fiscal Deficit, Debt Dynamics and Economic Growth In Nigeria. Retrieved 09 12, 2019, from Research Gate:

https://www.researchgate.net/publication/284443226_Fisc al_Deficit_Debt_Dynamics_and_Economic_Growth_in_N igeria

[25] Reinhart, C. M., \& Rogoff, K. S. (2010). "Growth in a Time of Debt." American Economic Review: Papers \& Proceedings , Vol. 100 (2): pp.573-78. Retrieved from American Economic Review: Papers \& Proceedings 100 (May 2010): 573-578: https://scholar.harvard.edu/files/rog off/files/growth_in_time_debt_aer.pdf

[26] Roberts, R. O. (1942). Ricardo's Theory of Public Debts. Retrieved 09 18, 2019, from JSTOR: https://www.jstor.org /stable/2549539

[27] Siddique, A., Selvanathan, E., \& Selvanathan, S. (2016). "The Impact of External Debt on Economic Growth: Empirical Evidence from Highlt Indebted Poor Countries". Journal of Policy Modeling, Volume 38, Issue 5, pp. 874-894. Retrieved from Science Direct:https://doi.org/10. 1016/j.jpolmod.2016.03.011

[28] Sulaiman, L., \& Azeez, B. (2012). "Effect of External Debt on Economic Growth of Nigeria." Retrieved 09 12, 2019, from Journal of Economics and Sustainable Development IISTE: https://iiste.org/Journals/index.php/JEDS/issue/vie w/364

[29] Von Moltke, K. (1990). International Issues in Tropical Deforestation. Paper Prepared for the Workshop on Climate Change and Tropical Forests, Sao Paulo.

[30] Were, M. (2001). The Impact of External Debt on Economic Growth in Kenya: An Empirical Assessment. Helsinki: United Nations University/World Institute for Development Economics Research - Discussion Paper No. 2001/116.

[31] World Bank, www.worldbank.org (various years 